Table 2 Specific binding of ${ }^{3} \mathrm{H}$-oestradiol to intact and operated mammary glands of unilaterally thelectomised rats

${ }^{3} \mathrm{H}$-oestradiol bound

(fmol per mg cytosol protein*)

\begin{tabular}{|c|c|c|c|}
\hline Rats & $\begin{array}{l}\text { Intact } \\
\text { mammary } \\
\text { gland }\end{array}$ & $\begin{array}{l}\text { Thelectomised } \\
\text { mammary } \\
\text { gland }\end{array}$ & Significance \\
\hline $\operatorname{Virgin}(n=4)$ & $10.8 \pm 5.1$ & $9.25 \pm 4.75$ & NS \\
\hline $\begin{array}{l}\text { Early pregnancy }(1-11 \\
\text { days })(n=6)\end{array}$ & $6.7 \pm 5.4$ & $10.2 \pm 10.3$ & NS \\
\hline $\begin{array}{l}\text { Late pregnancy }(12- \\
22 \text { days })(n=9)\end{array}$ & $4.9 \pm 4.1$ & $4.3 \pm 5.7$ & NS \\
\hline $\begin{array}{l}\text { Early lactation }(2-7 \\
\text { days) }(n=6)\end{array}$ & $8.7 \pm 4.1 \dagger$ & $4.7 \pm 3.8$ & NS \\
\hline $\begin{array}{l}\text { Late lactation }(8-21 \\
\text { days) }(n=7)\end{array}$ & $20.9 \pm 15.1$ & $5.0 \pm 3.7$ & $P<0.02$ \\
\hline $\begin{array}{l}\text { Weaned (5-12 days) } \\
\quad(n=6)\end{array}$ & $8.6 \pm 4.1$ & $3.2 \pm 3.1$ & $P<0.03$ \\
\hline
\end{tabular}

Oestradiol binding was assayed in the cytosol fraction $(100,000 \mathrm{~g}$ supernatant). Cytosol plus buffer $(500 \mu \mathrm{l})$ was incubated overnight $\left(5^{\circ} \mathrm{C}\right)$ with saturating amounts $(2 \mathrm{pmol})$ of $\left[6,7-{ }^{3} \mathrm{H}\right]$ oestradiol $-17 \beta$ (44 $\mathrm{Ci} \mathrm{mol}^{-1}$, Radiochemical Centre, Amersham) in the absence and presence of unlabelled oestradiol $(2 \mathrm{nmol})$. Unbound steroid was removed by incubation at $0^{\circ} \mathrm{C}$ for $15 \mathrm{~min}$ with dextran-coated charcoal ( $1 \mathrm{ml} 0.5 \%$ activated charcoal, Sigma, $0.05 \%$ dextran T 80 , Pharmacia). Charcoal was precipitated by centrifugation $(1,500 \mathrm{~g}$ for $10 \mathrm{~min})$ and the supernatants decanted into $10 \mathrm{ml}$ Instagel scintillation phosphor (Packard) and the radioactivity determined using a Packard TriCarb B2450 liquid scintillation counter, with automated external quench correction. The binding was specific for oestrogens being displaced by oestradiol and diethylstilboestrol, but not by testosterone, dexamethasone, cortisol or progesterone. Values are means \pm s.d.; $n=$ no. of observations; NS, not significant, $P>0.05$.

* Protein measured by a modified Lowry method ${ }^{18}$.

$\dagger P=0.03$ versus mammary gland in late pregnancy.

When teats are blocked, ligated or removed, milk accumulates in the mammary gland. Early changes depend on whether the litter remains with the mother. If the litter is removed, then even in intact glands milk accumulates and mammary blood flow falls within $8 \mathrm{~h}$ as a result of reduced cardiac output and a reduced proportion of cardiac output being taken by the mammary gland ${ }^{15}$. If, as in the present experiments, suckling continues but milk removal is prevented, then even more milk collects in the tissue but the blood flow does not fall ${ }^{15}$. However, by $36-48 \mathrm{~h}$ capillary closure occurs in the mammary gland whether suckling occurs or not ${ }^{5}$, and there is marked reduction in metabolic activity ${ }^{1-3}$. The collapse of the capillary bed can be seen by blanching of the tissue and was further demonstrated by Silver ${ }^{5}$ by failure of the gland to give a milk ejection response to oxytocin administered intravenously, whereas a response could still be obtained if oxytocin was applied locally to the exposed surface of the gland. Capillaries remained empty beyond $120 \mathrm{~h}$ in suckled glands ${ }^{5}$. As involution progresses, the proportion of cardiac output going to the mammary gland falls, apparently regulated locally by depressed mammary activity ${ }^{15,16}$.

Our results indicate the importance of blood supply and rate of delivery of hormones to the tissue in the control of receptor levels. This could be of considerable importance in the regulation of receptor levels in breast cancer tissue, since angiogenesis, blood vessel development, is stimulated by neoplastic cells ${ }^{17}$.

We thank NIAMDD, Bethesda for the ovine prolactin and the Cancer Research Campaign for a grant; also Mrs L. Schofield and Miss K. Woodsell for technical assistance.

Received 5 November 1979; accepted 14 January 1980.

1. McLean, P. Biochem. J. 90, 271-278 (1964).

2. Jones, E. A. Biochim. biophys. Acta 177, 158-160 (1968)

3. Hamosh, M., Clary, T. R., Chernick, S. S. \& Scow, R. O. Biochim. biophys. Acta 210, 473-482 (1970).
4. Lyons, W. R. Proc. $R$. Soc, B149, 303-325 (1958)

Silver, I. A. J. Physiol., Lond. 133, 65-66P (1956)

6. Hayden, T. J., Bonney, R. C. \& Forsyth, I. A. J. Endocr. 80, 259-269 (1979)

7. Holcomb, H. H., Costlow, M. E., Buschow, R. A. \& McGuire, W. L. Biochim. biophys. Acta 428, 104-112 (1976).

8. Smith, R. D., Hilf, R. \& Senior, A. E. Cancer Res. 36, 3726-3731 (1976)

9. Bohnet, H. G., Gomez, F. \& Friesen, H. G. Endocrinology 101, 1111-1121 (1977).

10. Gardner, D. G. \& Whitliff, J. L. Biochim. biophys. Acta 320, 617-627 (1973).

11. Hsueh, A. J. W., Peck, E. J. \& Clark, J. H. J. Endocr. 58, 503-511 (1973).

12. Leung, B. S., Jack, W. M. \& Reiney, C. G. J. Steroid Biochem. 7, 89-95 (1976).

13. Forsyth, I. A. \& Hayden, T. J. Symp. Zool. Soc. Lond. 41, 135-163 (1977).

4. Leung, B. S. \& Saski, G. H. Biochem. biophys. Res. Commun. 55, 1180-1187 (1973)

5. Hanwell, A. \& Linzell, J. L. J. Physiol., Lond. 233, 111-125 (1973).

16. Chatwin, A. L. Linzell, J. L. \& Setchell, B. P. J. Endocr. 44, 247-254 (1969).

17. Gullino, P. M. J. natn. Cancer Inst. 61, $639-643$ (1978).

18. Hartree, E. F. Analyt. Biochem. 48, 422-427 (1972).

\section{Novel expression-linked copies of the genes for variant surface antigens in trypanosomes}

\author{
J. H. J. Hoeijmakers, A. C. C. Frasch, A. Bernards, \\ P. Borst \& G. A. M. Cross*
}

Section for Medical Enzymology and Molecular Biology, Laboratory of Biochemistry, University of Amsterdam, Jan Swammerdam Institute, PO Box 60.000, 1005 GA Amsterdam, The Netherlands

*The Wellcome Research Laboratories, Department of Immunochemistry, Langley Court, Beckenham, Kent BR3 3BS, UK

Pathogenic African trypanosomes evade the immune system of their mammalian hosts by the sequential expression of alternative cell-surface glycoproteins (reviewed in refs 1,2 ). Variant surface glycoproteins (VSGs) purified ${ }^{3}$ from cloned variants of Trypanosoma brucei have similar molecular weights (about $60,000)$, but differ in amino acid composition ${ }^{3}$, $\mathrm{N}$-terminal amino acid sequence ${ }^{4}$ and $C$-terminal structure ${ }^{5}$. We have cloned DNA complementary to the messenger RNAs for four immunologically distinct VSGs $^{6}$ and hybridised these complementary DNAs (cDNAs) with restriction digests of $T$. bruce $i$ nuclear DNA, fractionated by gel electrophoresis and transferred to nitrocellulose strips. Each cDNA recognises a unique set of fragments and this basic set is present unaltered in the nuclear DNAs from the four variants. In addition, each probe recognises an extra fragment only in nuclear DNA isolated from cells expressing the VSG corresponding to the cDNA probe. We infer that activation of a VSG gene involves the production of an expression-linked copy of that gene.

The cDNA clones used in our experiments were originally identified $^{6}$ on the basis of their ability to hybridise only to $\operatorname{poly}(\mathrm{A})^{+} \mathrm{RNA}$ from the homologous variant and this specificity is further documented in Fig. 1. Total poly $(\mathrm{A})^{+}$RNA from all four variants of $T$. brucei, strain 427 , was size-fractionated by agarose gel electrophoresis (Fig. 1a), covalently linked to paper ${ }^{7}$ and then hybridised with one of the four cloned cDNAs. Figure $1 b$ shows that cDNA of variant 117 only hybridises with homologous RNA; the same was found with the other three cDNAs (not shown). The mobility of the RNA species that hybridise is variant dependent (Fig. 1c), the calculated size varying from 2,250 nucleotides (variant 117 ) to 1,950 nucleotides (variant 221$)^{6}$. This variation correlates with the apparent molecular weights of the corresponding pre-VSGs, deduced from their mobilities in SDS polyacrylamide gels. These decrease in the same order, 117 being $62,000,221$ being 52,000 (ref. 6).

The genes corresponding to these VSG-specific cDNAs were analysed by the Southern blotting technique ${ }^{8}$. Nuclear DNA from one $T$. brucei variant was digested with various restriction endonucleases, size-fractionated by agarose gel electrophoresis, blotted on to nitrocellulose strips and hybridised with each of the four cDNAs. Figure 2 shows results with three of these. Each 
bands attributable to the basic 118 VSG gene in variant 117 and variant 118 DNA. Also, the extra bands hybridise at approximately the same intensity as the bands from the basic copy, allowing for a less efficient transfer of large bands in blotting experiments. Our results, therefore, suggest that the expressionlinked copy is an extra copy of the 118 VSG gene. This would

$$
a b c d e f g h i j k l m n \text { o p }
$$

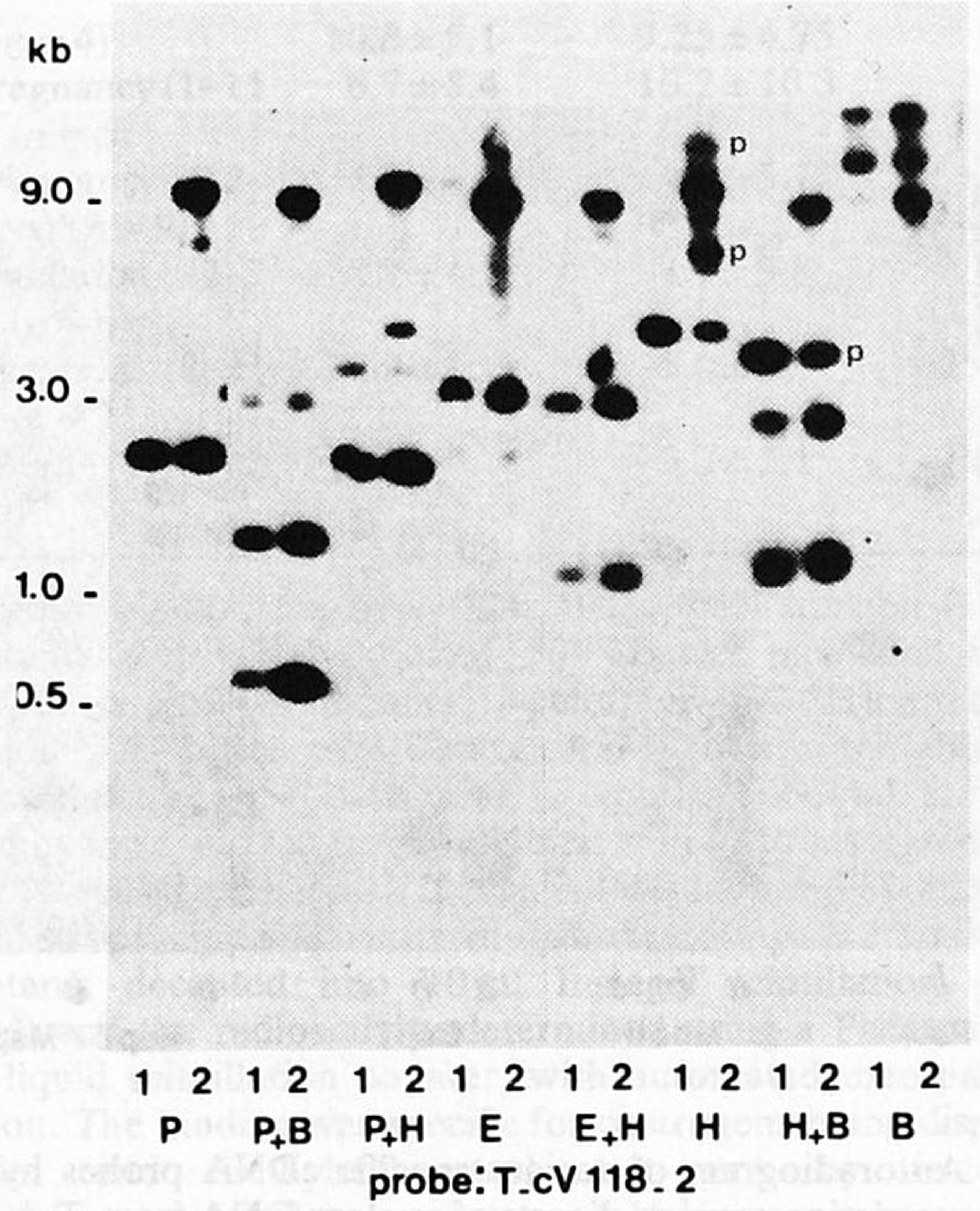

Fig. 3 Hybridisation of DNA complementary to VSG 118 mRNA to nuclear DNA digests of variants 117 and 118 . The restriction digests were electrophoresed through a $0.7 \%$ agarose gel. Further conditions as in Fig. 2. The $p$ marks persistent partial HindIII digestion products, absent in other experiments. Lane 1, nDNA 117; lane 2, nDNA 118; P, PstI; B, BamHI; H, HindIII; E, EcoRI.

imply the presence of minimally two basic and two expressionlinked copies of this gene per nucleus, if trypanosomes are diploid. The ploidy of Trypanosoma is not known, however, and the available data on DNA complexity (A.C.C.F. and P. B., unpublished) and the amount of DNA per cell ${ }^{11}$ are so imprecise that they are compatible with anything between haploid and tetraploid.

To account for the results of the blotting experiments, the formation of the expression-linked copy must be associated by a reshuffling of DNA sequences which alters the neighbouring sequences. This reshuffling could either move the gene into a new (expression) site ${ }^{12-14}$, as in the casette mechanism for mating-type switching in yeast ${ }^{14}$, or an insertion sequence could be put next to the extra copy ${ }^{15}$. Whatever the mechanism, the sequences flanking the expression-linked copy of the VSG 118 gene are unusual in that at one side no PstI, HindIII, BamHI or EcoRI site is present within 8 kilobase pairs of the gene. It is interesting that large extra bands have also been observed when the $117 \mathrm{cDNA}$ is hybridised with 117 nuclear DNA cleaved with MspI (Fig. 4), PstI or EcoRI. The flanking sequence, may, therefore, be similar whatever alternative gene is being expressed. The simplest interpretation of our results is that the expression-linked copy is the one transcribed and that the novel flanking sequences are responsible for this; however, this remains to be confirmed.

The recombination event that we expect to be responsible for the positioning of the extra copy in the postulated expression site could easily be accompanied by further recombination events that increase sequence diversity in the VSG genes. There is no

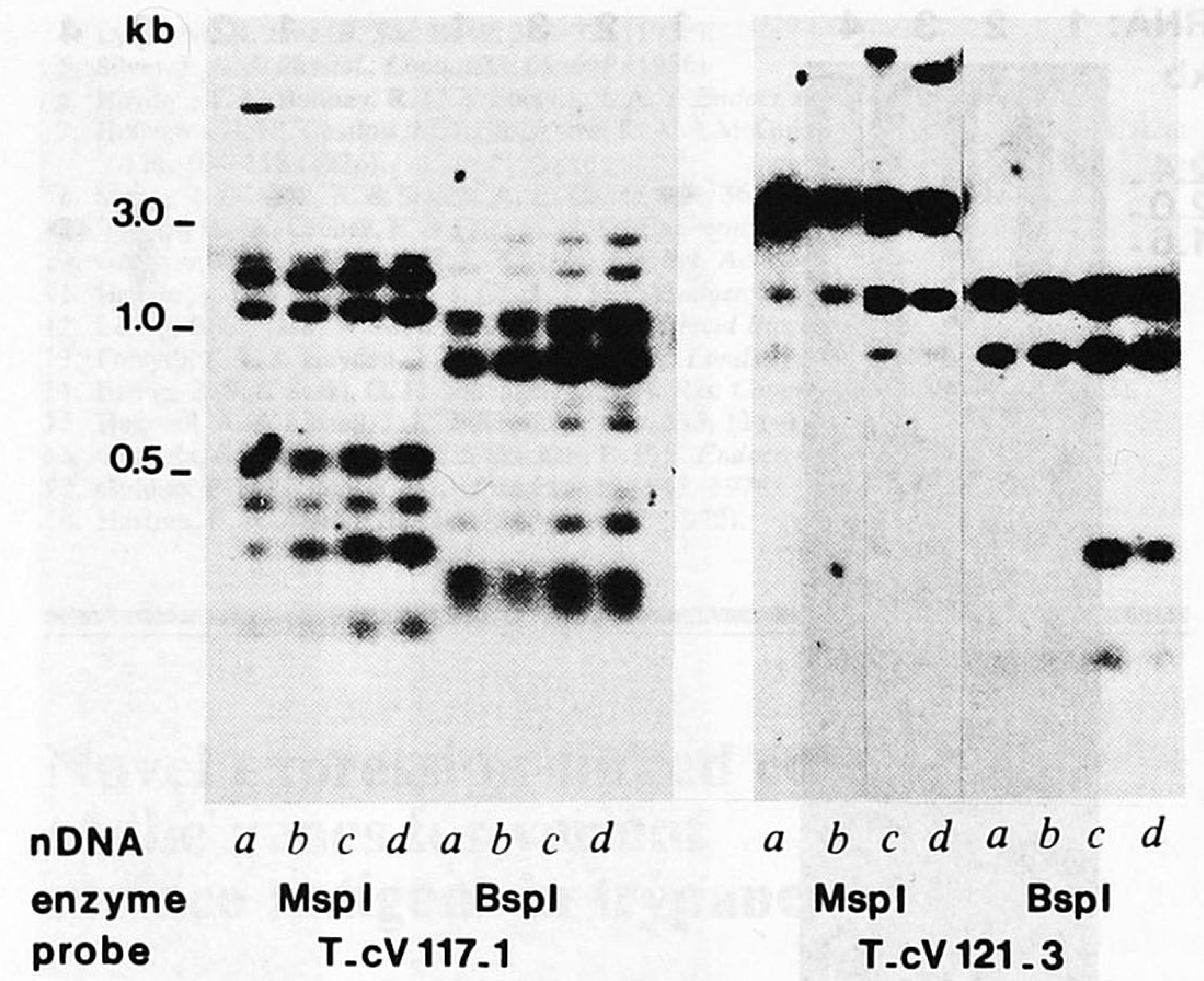

Fig. 4 Autoradiogram showing hybridisation of VSG-specific cDNA probes with homologous and heterologous nuclear DNAs. Nuclear DNA from the four variants indicated was electrophoresed through a $1.2 \%$ agarose gel; see Fig. 2 legend for further details. nDNA: $a, 117 ; b, 118 ; c, 121 ; d, 221$.

evidence for this either in previous work on VSGs (refs 2-5 and G.A.M.C., unpublished) and their genes ${ }^{6}$, or in our present experiments, as the expression-linked copy is not recognised by the heterologous probes tested. It seems likely, therefore, that antigenic diversity in trypanosomes is genomic and finite and not created by a clever reassortment of a limited number of DNA sequences to yield an unlimited number of VSG genes. It is possible, however, that the novel flanking sequence in the expression site provides not only a promotor but also the 5 -leader sequence and signal peptide (if present) for each VSG. This can be tested when genomic clones are available; work is in progress to obtain them.

Williams and coworkers ${ }^{18}$ have also observed rearrangement of DNA associated with expression of another line of T. brucei. In their case, however, there is no clear conservation of bands associated with a basic copy and, moreover, there are also alterations in another clone apparently not associated with expression. We cannot account for this crucial difference from our results.

We thank Miss J. Van den Burg and Mr M. J. Hillebrand for assistance and Professor C. Weissmann for providing plasmid DNAs. This work was supported in part by a grant to P.B. from BION (ZWO) and a Research Training Grant to A.C.C.F. from WHO.

Recieved 10 December 1979; accepted 18 January 1980.

1. Vickerman, K. Nature 273, 613 (1978).

2. Cross, G.A.M. Proc. R. Soc. B202, 55 (1978).

3. Cross, G.A.M. Parasitology 71, 393 (1975).

4. Bridgen, P. J., Cross, G. A. M. \& Bridgen, J. Nature 263, 613 (1976).

5. Johnson, J. G. \& Cross, G. A. M. Biochem. J. 178, 689 (1979)

6. Hoeijmakers, J. H. J., Borst, P. Van den Burg, J., Weissmann, C. \& Cross, G. A. M. Gene 8 391 (1980)

7. Alwine, J. C., Kemp, D. J. \& Stark, G. R. Proc. natn. Acad. Sci. U.S.A. 74, 5350 (1977). 8. Southern, E. M. J. molec. Biol. 98, 503 (1975).

9. Waalwijk, C. \& Flavell, R. A. Nucleic Acids Res. 5, 3231 (1978).

10. Doyle, J. J., Hirumi, H., Hirumi, K., Lupton, E. N. \& Cross, G. A. M. Parasitology (in the press).

11. Riou, G. \& Pautrizel, R. J. Protozool 16, 509 (1969).

12. Kamp, D., Kahmann, R., Zipser, D., Broker, T. R. \& Chow, L. T. Nature 271, 577 (1978).

13. Zieg, J., Hillmen, M. \& Simon, M. Cell 15, 237 (1978).

14. Strathern, J. N., Newlon, C. S., Herskowitz, I. \& Hicks, J. B. Cell 18, 309 (1979).

15. Bukhari, A. I., Shapiro, J. A. \& Adhya, S. L. (eds) DNA: Insertion, Elements, Plasmids, and Episomes (Cold Spring Harbor Laboratory, New York, 1977).

16. Van Ommen, G. J. B., Groot, G. S. P. \& Grivell, L. A. Cell 18, 511 (1979).

17. Borst, P. \& Fase-Fowler, F. Biochim. biophys. Acta 565, 1 (1979).

18. Williams, R. O., Young, J. R. \& Majiwa, P. A. O. Nature 282, 847 (1979). 